\title{
Genetic breeding on the bee Melipona scutellaris (Apidae, Meliponinae)
}

\author{
José de Ribamar SILVA BARROS ${ }^{1}$
}

\begin{abstract}
A selection of queens of Melipona scutellaris through the most productive colonies were carried out during eight months in an orange honeyflow. Each of the colonies was evaluated by its production, that is, the gross weight production ( pollen, brood, geopropolis and wax of each hive). With this data a coefficient of repeatability was estimated by the intraclass correlation method, obtained $\mathrm{r}=0.835 \pm 0.071$. The repeatibility is very high showing that the analysed data (production) is repeatable. Selection was then carried out using the regression coefficient of each colony and the respective production gain. Using these data the colonies were divided into three groups according to the method Vencovsky and Kerr (1982): a with the colonies of highest productivity, $\mathbf{b}$ of least productivity, and $\mathbf{c}$ of intermediary productivity. Colonies with the highest production (Group a) gave their queens to those of the lowest production (Group b) after their queens were taken out and killed; while those of intermediate (Group c) stayed with the same queens during the entire experiment both before and after the selection. The modifications in weight, that is, the genetic response was $(\hat{R})=7.98$ gr per day which indicated a selection gain. The estimate of the realized herdability is twice the rate of the response to selection $(\hat{R})$ by the selection differential $\left(\mathrm{S}_{2}\right)$. That is $\hat{h}_{R}^{2}=2\left(\hat{R} / S_{2}\right)$ then $\hat{h}_{R}^{2}=$ 0.166
\end{abstract}

\section{PALAVRAS-CHAVE}

Melhoramento, abelha, Melipona scutellaris,Apidae.

\section{Melboramento genético na abelba Melipona scutellaris (Apidae, Meliponinae)}

\begin{abstract}
RESUMO
Foi feita uma seleção de rainhas durante oito meses com 10 colônias aproveitando uma florada de laranjeiras. Cada colônia teve sua produção total (mel, pólen, crias, geoprópolis e cera) avaliada. Estimamos com estes dados o coeficiente de repetibilidade por meio de uma correlação intraclasse e obtivemos $r=0.835 \pm 0,071$. Esse valoré alto e mostra que a produção de cada colônia érepetível. Executamos uma seleção usando o coeficiente de regressão de cada colônia e o respectivo ganho de produção . No uso desses dados, as colmeias foram divididas em três grupos, de acordo com o método de Vencovsky e Kerr (1982): a contendo as colônias de maior produtividade; $\boldsymbol{b}$ com as colônias que apresentaram menor produtividade e com as colônias de produção intermediárias. As colônias com maior produção (grupo a) deram suas rainhas para aquelas com menor produção (grupo b) cujas rainhas foram retiradas e mortas. As colônias do grupo c permaneceram com suas próprias rainhas durante todo o experimento tanto antes como depois da seleção.As modificações no peso, quer dizer, a resposta genética ocorrida foi $(\hat{R})=7.98$ gramas por dia, indicando um ganbo proveniente da seleção. A estimativa da herdabilidade é o dobro da resposta à seleção dividida pela seleção diferencial $\left(S_{2}\right)$, ou seja: , $\log o=0,166$.
\end{abstract}

\section{KEYWORDS}

Breeding, selection, Melipona, bee.

${ }^{1}$ Departamento de Biologia da Universidade Estadual do Maranhão-UEMA-65054-970 São Luís, MA, Brasil 


\section{INTRODUCTION}

Many papers have been produced using populations of the honey bee Apis mellifera L. (Collins, 1986; Kulincevic, 1986; Laidlaw and Page, 1986; Rinderer, 1986;Vencovsky and Kerr, 1982). There are about 100 Brazilian species of stingless bees that produce excellent honey, but had never been subjected to direct genetic improvement. Three of these species have been domesticated by pre-Columbian human populations: Melipona beecheii,Bennett the Yucatanian cab; Melipona compressipes Fabricius, the tiuba of Maranhão; and Melipona scutellaris Latreille the Northeastern Brazilian bee urussú. The present work is part of a larger study being carried out on the stingless bees .(Meliponinae).

\section{MATERIAL AND METHODS}

This work was conducted at the State University of São Paulo (UNESP), on the campus of Jaboticabal, State of São Paulo. Among the 21 colonies of Melipona scutellaris, only 10 colonies were used for this specific experiment. No information on either resistence to migration or on the behavior of these bees in orange flowers were available. The evaluation period of the hives extended from August, 10, 1992 to March 3, 1993. All hives were in the same environment: in the absence of nectar flow, colonies were fed syrup ( $50 \%$ water plus $50 \%$ commercial sugar and a pill of Teragran - M) or 50\% commercially rejected honey of Apis mellifera L., because it was collected by the honey bees in sugar cane stacks produced after burning the straws.

In order to discover the production of a specific colony at different months, a coefficient of repeatability was estimated, using data obtained on the weight of the all hives with $M$. scutellaris bees. This coefficient set the superior limit of herdability and includes additive effects of genes plus nonadditive effects and the permanent environmental differences existent among colonies. The method used was intraclass correlation (Fisher 1954). The following statistical model was used:

$$
\mathrm{Y}_{\mathrm{ij}}=\mathrm{u}+\mathrm{a}_{\mathrm{i}}+\mathrm{e}_{\mathrm{ij}} \quad \text { where: }
$$

$Y_{i j}=$ Production $j$ within the hive $i(j=1,2, \ldots, 8 ; i=1,2, \ldots, 10)$.

$\mathrm{u}=$ general media effect

$a_{i}=$ colony $i$ effect $(i=1,2 \ldots .10)$

$\mathrm{e}_{\mathrm{ij}}=$ aleatory error.

Table 1 shows the variance analysis model of the variance components used to estimate repeatability.

Production repeatibility of colonies was estimated from variance components obtained using the above model followed by:

$$
r=\frac{\sigma_{c}^{2}}{\sigma_{c}^{2}+\sigma_{e v}^{2}} \quad \text { where: }
$$

Table 1 - Variance analysis model for obtaining the components used for estimating the repeatability in colonies of Melipona scutellaris.

\begin{tabular}{llll}
\hline $\begin{array}{l}\text { Sources of } \\
\text { variation }\end{array}$ & D.F. & Q.M. & E (Q.M.) \\
$\begin{array}{l}\text { Between } \\
\text { colonies }\end{array}$ & $\mathrm{C}-\mathrm{I}$ & $\mathrm{QM}_{2}$ & $\sigma_{e v}^{2}+k \sigma_{c}^{2}$ \\
$\begin{array}{l}\text { Within } \\
\text { colonies }\end{array}$ & $\mathrm{N}-\mathrm{C}$ & $\mathrm{QM}_{1}$ & $\sigma_{e v}^{2}$ \\
\hline \hline
\end{tabular}

$r=$ repeatability coefficient

$\sigma_{c}^{2}=$ colony variance coefficient

$\sigma_{e v}^{2}=$ environment variance component

The standard error of the repeatability coefficient

( $\delta$ r) was obtained by the formula (Fisher 1954):

$\delta_{r}=\sqrt{\frac{2(1-r)^{2}[1+(k-1) r]^{2}}{k(k-1)(n-1)}} \quad$ where:

$r=$ repeatability coefficient

$k=$ number of colonies

$n=$ total number of observations

\section{DIRECTIONAL SELECTION (S)}

The directional selection was made based on the weight of the hives. A regression coefficient was estimated for the gross weight (in grams) of each hive, relative to time $(x=0$, $30,60, \ldots, 210$ days).

Based on the preliminary data obtained from these estimates, colonies were divided into three groups:

$\mathbf{a}=$ Three colonies with the largest regression coefficients.

$\mathbf{b}=$ Three colonies with the smallest regression coefficients.

c $=$ Control group made up of 4 colonies with intermediate regression coefficients.

The method of selection used, developed by Vencovsky and Kerr (1982), runs as follows:

About $25 \%$ of the best colonies (as in this present case the aim was total colony weight; the "best colonies" were the 3 heaviest) have their three queens (Group a) removed and introduced in the $25 \%$ worst colonies (the 3 lightest ones ) Group b - that previously had their 3 queens removed and killed. The workers of the three best colonies each choose a virgin queen that takes the nuptial flight, and usually begins egg laying within 14 days. This selection process (and queen 


\section{ACTA \\ AMAZONICA}

supersedure) was carried out on the 3rd of April, 1993, after 210 days ( 7 months) migration of the bees to and from an enormous orange honey flow.

The selection diferential was estimated by the diference of the mean regression coefficient of Group a and the mean linear regression coefficient of the population.

\section{ANSWER TO SELECTION $(\hat{R})$}

The answer to selection was quantified through the estimates of the linear regression coefficients, and was considered as being the result of the difference of the mean linear regression coefficients of the colonies of the groups a and $\mathbf{b}$ after and before the selection, through the linear mean regression coefficients of Group c (= control group), after and before selection.

$$
\hat{R}=\left(\hat{b}_{a b 1}-\hat{b}_{a b 0}\right)-\left(\hat{b}_{c 1}-\hat{b}_{c 0}\right)
$$

$\hat{R}=$ Estimate genetic answer to selection

$\hat{b}_{a b 0}=$ Estimate of the mean linear regression coefficient of the colonies belonged to Group $\mathbf{a}$ and $\mathbf{b}$ before selection.

$\hat{b}_{a b 1}=$ Estimate of the mean linear regression coefficient of the colonies of the Group c (control) before selection.

$\hat{b}_{c 1}=$ Estimate of mean linear regression coefficient of the colonies that belong to Group c (control) after selection.

$\hat{b}_{c 0}=$ Estimate of mean linear regression coefficient of the colonies that belong to Group c (control) before selection.

\section{REALIZED HERDABILITY $\left(h_{R}^{2}\right)$}

The realized herdability was estimated as being two times the rate of the selection $(R)$ by the selection differential (S); both were estimated based on the regression. The result was multiplied by 2 , due to the data which was based on the mother effect, since all mates were randon.

\section{RESULTS AND DISCUSSION}

\section{Genetic Selection}

The data based on to the gross weight production of the 10 colonies of Melipona scutellaris are in Table 2 and 3.

The results of the variance analyses obtained from the data of the gross weight of the hives (table 2 and 3 ) allowed the estimation of the repeatability coefficient, as presented in table 4.

According to the analysis of variance (see Table 4) a significative effect is indicated $(\mathrm{P}<0.01)$ which may infer that the colonies are different as far as weight is concerned.

\section{REPEATABILITY ( $R$ )}

The estimate of repeatability for production for the experimental colonies was $r=0.8346 \pm 0.71$. This is a very high value and means that the observations present the real capacity of production of the colonies in order to carry out a selection program.

\section{SELECTION OF COLONIES}

Queens of meliponids are usually inseminated by one male.The data obtained recently by Carvalho (2001) for this species shows that $8 \%$ of their queens are inseminated by two males. The selection of queens must be made through the performance of the colonies.

Table 5 shows the estimates of the regression coefficients of 10 colonies of Melipona scutellaris before and after selection of the queens.

As can be seen in Table 5, the constitution of the groups according to the regression coefficients is:

Group a: superior colonies, with the greatest regression coefficients: k 419, k309, k430.

Table 2 - Gross weights in grams of 10 colonies of Melipona scutellaris, with respective means $(\bar{x})$ and standard deviation ( s ) before selection.

\begin{tabular}{lllllllllll}
\hline \multicolumn{2}{c}{ Hives } & & & & & & & & \\
Days & k426 & k427 & k419 & k309 & k436 & k418 & k295 & k431 & k428 & k430 \\
\hline 0 & 4420 & 5360 & 5280 & 4460 & 5160 & 6200 & 4580 & 5200 & 5080 & 4880 \\
30 & 4400 & 5360 & 5580 & 4680 & 5120 & 6320 & 4700 & 5180 & 5160 & 5000 \\
60 & 4340 & 5320 & 5900 & 4800 & 5120 & 6300 & 5000 & 5180 & 5280 & 5120 \\
90 & 4320 & 5320 & 5900 & 4960 & 4860 & 6300 & 4820 & 5120 & 5300 & 5000 \\
120 & 4280 & 5040 & 5600 & 4900 & 4960 & 6100 & 4660 & 5000 & 5280 & 4960 \\
150 & 4380 & 5060 & 5680 & 5240 & 4880 & 6100 & 4720 & 4940 & 5500 & 5160 \\
180 & 4340 & 5120 & 5900 & 5540 & 4940 & 6240 & 4820 & 4920 & 5500 & 5620 \\
210 & 4340 & 5180 & 5940 & 5800 & 5300 & 6400 & 4960 & 4900 & 5400 & 5900 \\
$X$ & 4352.5 & 5220.0 & 5722.5 & 6687.5 & 5042.0 & 6245.0 & 4782.5 & 5055.0 & 5312.0 & 5205.0 \\
$S$ & 45.2729 & 135.6466 & 231.3779 & 846.7754 & 155.4487 & 106.7709 & 145.5777 & 128.1740 & 150.0238 & 361.3862 \\
\hline \hline
\end{tabular}


Table 3 - Gross weights in grams of 9 colonies of Melipona scutellaris, with respective means $(\bar{x})$ and standard deviation $(\mathrm{s})$ after selection.

\begin{tabular}{llllllllll}
\hline \multicolumn{2}{c}{ Hives } & & & & & & & & \\
Days & k426 & k427 & k419 & k309 & K436 & k418 & k295 & k431 & k428 \\
\hline 0 & 4380 & 4960 & 6500 & 5600 & 5000 & 6280 & 4880 & 4900 & 5400 \\
30 & 4600 & 5000 & 6580 & 5680 & 5060 & 6000 & 4840 & 5020 & 6460 \\
60 & 5000 & 6340 & 6540 & 6000 & 5200 & 6080 & 5200 & 5700 & 5860 \\
90 & 5300 & 6060 & 7080 & 6220 & 5560 & 6940 & 5500 & 6880 & 7080 \\
120 & 5900 & 6060 & 7620 & 6320 & 5560 & 7760 & 5800 & 6960 & 7980 \\
$X$ & 5036.00 & 5684.00 & 6864.00 & 5978.00 & 5235.00 & 6612 & 5240 & 5892 & 6556 \\
$\mathrm{~S}$ & 599.5665 & 652.9012 & 483.8181 & 334.0958 & 225.6546 & 740.4863 & 409.9756 & 987.1778 & 1016.4054 \\
\hline \hline
\end{tabular}

Table 4 - Summary of variance analysis of the gross weights of ten hives of Melipona scutellaris (from 10 Aug 92 to 10 Mar 93).

\begin{tabular}{lccl}
\hline \hline $\begin{array}{l}\text { Source of } \\
\text { variation }\end{array}$ & DF & MS & F \\
\hline $\begin{array}{l}\text { Between } \\
\text { colonies }\end{array}$ & 9 & 207968.89 & $41.37^{* *}$ \\
$\begin{array}{l}\text { Within } \\
\text { colonies }\end{array}$ & 70 & 50267.14 & \\
\hline \hline
\end{tabular}

Group b: inferior colonies with the smallest regression coefficients: k 426, k 427, k431.

Group c: control colonies with intermediate regression coefficients : k436, k418, k295, k428.

\section{DIFFERENTIAL SELECTION}

There are two considerations to be made as far as the differential selection obtained through the estimation of the mean linear regression coefficients are concerned.

a) The selecion differential $\left(S_{1}\right)$ that takes in account all colonies envolved in the bee reproduction before selection:

$$
\begin{aligned}
& \mathrm{S}_{1}=\hat{b}_{a 0}-\hat{b}_{p} \\
& \mathrm{~S}_{1}=121.11-33.90 \\
& \mathrm{~S}_{1}=87.21 \text { grams }
\end{aligned}
$$

b) The selection differential $\left(\mathrm{S}_{2}\right)$ utilized in the estimation of realized herdability, took in account only nine colonies (since hive $\mathrm{K} 430$ died due to the production of diploid males):

$$
\begin{aligned}
& \mathrm{S}_{2}=\hat{b}_{a 0}-\hat{b}_{p} \\
& \mathrm{~S}_{2}=120.24-24.02 \\
& \mathrm{~S}_{2}=96.22 \text { grams }
\end{aligned}
$$

The size of the two selection differential shows the phenotypic superiority of queens selected even if one colony died (due to diploid drone production). Evidently, any selection event must take into account that some colonies will die or at least be weakened due to sex-alleles.
Table 5 - Exstimates of the regression coefficients before $\left(\hat{b}_{0}\right)$ and $\operatorname{after}\left(\hat{b}_{a}\right)$ the selection of queens of Melipona scutellaris.

\begin{tabular}{llll}
\hline \hline Rank & Colonies & $\hat{b}_{0}$ & $\hat{b}_{a}$ \\
\hline 01 & $\mathrm{k} 426$ & $-9.28 \pm 6.52$ & $374 \pm 36.13$ \\
02 & $\mathrm{k} 427$ & $-41.90 \pm 14.78$ & $326 \pm 146.33$ \\
03 & $\mathrm{k} 431$ & $-50.48 \pm 5.63$ & $598 \pm 103.61$ \\
04 & $\mathrm{k} 419$ & $62.62 \pm 28.87$ & $274 \pm 78.65$ \\
05 & $\mathrm{k} 309$ & $177.86 \pm 18.70$ & $205 \pm 29.57$ \\
06 & $\mathrm{k} 430$ & $122.86 \pm 33.35$ & \\
07 & $\mathrm{k} 436$ & $-6.43 \pm 25.77$ & $140 \pm 16.00$ \\
08 & $\mathrm{k} 418$ & $2.38 \pm 17.77$ & $390 \pm 149.70$ \\
09 & $\mathrm{k} 295$ & $26.90 \pm 21.64$ & $250 \pm 39.71$ \\
10 & $\mathrm{k} 428$ & $54.52 \pm 11.39$ & $578 \pm 162.43$ \\
Mean ( 10 colonies) & $33.90 \pm 1.84$ & \\
Mean (9 colonies) & $24.02 \pm 1.86$ & $348.33 \pm 9.40$ \\
\hline \hline
\end{tabular}

\section{QUEENS' SUBSTITUTION}

Queens of Group a were introduced into colonies of Group b with no extra precautions, as mentioned by Monteiro and Kerrr (1990), and all were accepted. The queenless colonies of Group a had new queens emerge and accepted, and all carried out their respective nuptial flight on May, 1992. The new queen of colony k 430 was inseminated by a male with one $x o$ sex allele equal to one of the two of the queens which lead to a segregation not different from 1:1 ( $1 / 2$ females to $1 / 2$ diploid males). Usually two events of diploid male production caused the colony to die out.

\section{RESULT OF THE SELECTION ( R )}

The estimates of the selection results were obtained by the differences between the mean linear regression coefficients of the Groups a and $\mathbf{b}$ before and after the selection by the estimate of the mean linear regression coefficient of the control Group c also after and before the selection for nine colonies of Melipona scutellaris 
Table 6 - shows the values of the estimates of the mean coefficient of regression of groups $a, b, a+b$ and $c$, before and after selection of queens.

\begin{tabular}{lll}
\hline \hline GROUPS & BEFORE & AFTER \\
\hline $\mathrm{a}$ & $\hat{b}_{a 0}=120.24 \pm 11.89$ & $\hat{b}_{a 1}=239.5 \pm 27.05$ \\
$\mathrm{~b}$ & $\hat{b}_{b 0}=-33.89 \pm 2.99$ & $\hat{b}_{a 1}=432.66 \pm 31.78$ \\
$\mathrm{a}+\mathrm{b}$ & $\hat{b}_{a b 0}=27.76 \pm 2.98$ & $\hat{b}_{a b 1}=355.4 \pm 15.77$ \\
$\mathrm{c}$ & $\hat{b}_{c 0}=19.34 \pm 4.78$ & $\hat{b}_{c 1}=339.5 \pm 22.99$ \\
\hline \hline
\end{tabular}

The queens of control Group c remained the same from the begining of the experiment. Therefore, the difference between the mean linear regression coefficients of these four colonies, before and after selection, provides the non-genetic variation that occured during this entire experiment.

The phenotypic variation that occured in the colonies of Groups $\mathbf{a}$ and $\mathbf{b}$ are made of both genetic and non genetic components, since there were chances of queens from Group a to Group b. The new queens of Group a are daughters of the queens that headed each Group a colony and, therefore, they have half of the addidive inheritance:

$$
\begin{aligned}
& \hat{R}=\left(\hat{b}_{a b 1}-\hat{b}_{a b 0}\right)-\left(\hat{b}_{c 1}-\hat{b}_{c 0}\right) \\
& \hat{R}=7.98 \text { grams } / \text { day }
\end{aligned}
$$

Another important component to be considered is the environmental effect $(E)$ that was obtained through the difference of the estimates of the mean linear regression coefficients of the colonies of the control group after and before selection.

$$
E=\hat{b}_{c 1}-\hat{b}_{c 0} ; E=319.66 \text { grams/day. }
$$

The size of this value indicates a great environmental variation during the period of the experiment. In the begining of the evaluation the ten colonies were taken from Jaboticabal to an orange plantation (Monte Alto city), from August to October, 1992; in October they were returned to Jaboticabal where they remained until July 1993, and went to Bebedouro/ SP to use the orange honey flow.

\section{REALIZED HERDABILITY $\left(h_{R}^{2}\right)$}

The estimate of the realized herdability is twice the rate of the answer to selection $(\hat{R})$ by the selection differential $\left(\mathrm{S}_{2}\right)$

$$
\hat{h}_{R}^{2}=2\left(R / S_{2}\right) ; h_{R}^{2}=0.166
$$

The value of the realized herdability was inferior to those cited by Collins (1986) for Apis mellifera $\mathrm{L}$. according to the following works:

a) Soller and Bar-Cohen (1967) found a value of $b^{2}=0.36$ for orange honey production in one generation of selection;

b) Rothenbuhler et al. (1979) found values of realized herdability for rapid line syrup collection of $h_{R}^{2}=0.553$ and for slow line syrup collection of $h_{R}^{2}=0.324$;

c) Hellmich et al. (1985) encountered values for pollen collection in the high line of $b^{2}=0.556 \pm 161$ and $b^{2}=0.063$ $\pm 0,190$ for the low line. The selection in the above items $\mathbf{a}$ and b was disruptive, that is, in two directions.

Pirchener (1969) considers that disruptive selection allows a better control of the environment. It is important to notice that our experiment had a control group of colonies.

\section{CONCLUSION}

The repeatability value was $r=0.8343 \pm 0.07$, which is a high value and indicates that there are more variations between colonies than within, sugesting that the method was robust.

The superiority of the selected colonies was shown through the selection differential with

$$
\mathrm{S}_{1}=87.21 \text { grams and } \mathrm{S}_{2}=96.22 \text { grams } \text {. }
$$

The answer to selection ( ) in the three groups involved in queen substitution was $=7.98$ grams per day and indicated that there was a genetic improvement in these groups. The three exceptional colonies that had their queens taken out produced new laying queens quickly, but one produced diploid males which shows that 10 hives make up a very small group and this suggests that experiments of this type should be made with 50 or more hives.

The value for realized herdability for honey production was $=0.164$, what is inferior those found in literature for Apis mellifera.

\section{SUMMARY}

Selection of queens of more productive colonies was carried out in 10 hives of Melipona scutellaris that were evaluated for eight months through its gross weight. The repeatability coefficient ( $r$ ) was estimated with these data using the intraclass correlation method. The production is a repetitive character of $r=0.8346 \pm 0.071$.

Selection was made with mean regression coefficient of each hive and of production gains. The colonies then constituted three groups: Group a of colonies with greater, Group b with colonies with less growth and Group c with hives of intermediate growth. Hives with greater growth (Group a) had their queens taken and introduced into those with lesser growth (Group b) that had its queens removed and killed; while the colonies of Group c remained with its respective queens during all periods before and after selection.

The genetic answer occured in the group related to queens substitution and was $=7.6$ grams $/$ day which indicates that there was an improvement in these groups. 
Realized herdability was estimated as being the rate between the answer to selection by the selection differential (S), then $=0.164$.

\section{ACKNOWLEDMENTS}

The author thanks: Prof. Dr. Warwick E. Kerr for being his tutor for the last 10 years. Prof. Dra. Regina Helena NogueiraCouto, as Head of the Dept. provided all help possible. Prof. Dr. Roland Vencovsky teached me quantitative genetics. FAPEMA - provided me with a studentship. $\mathrm{CNPq}$ - provided the funds for the research. Fac. C. Agr. e Vet. da Unesp - Jaboticabal gave the infra structure facilities. FAPEMIG gave the funds to assemble the Dept. of Genetics of the Federal University of Uberlândia.

\section{LITERATURE CITED}

Carvalho, G. A. 2001. The Number of Sex Alleles (CSD) in a Bee Population and its Practical Importance (Hymenoptera: Apidae), J. Hym. Res., 10 (1): 10-15

Collins, A.M. 1986. Quantitative Genetics . In Rinderer (ed), T.E., Bee Genetics and Breeding. Academic Press, Inc. , New York. p. 283-304.

Fisher, R. A. 1954. Statistical Methods for Research Workers. 12 ed. Oliver and Boyd, Edinburgh.

Hellmich, R. L.; II, Kulincevic, J. M.; Rothenbuler, W. C. 1985. Selection for high and low pollen-hoarding honey bees. $J$. Hered. 76:155 -158.

Kulincevic, J. M. 1986. Breeding accomplishments with Honey bees. In "Rinderer, T.H. (ed) Bee Genetics and Breeding. Academic Press, Inc., New York. p.391-414.
Laidlaw, H.H., JR and PAGE, Robert E. JR . 1986. Mating Designs. In Rinderer. T. H. Bee Genetics and Breeding. Acad. Press Inc., N. York. p.323-344.

Monteiro de Andrade, C.; Kerr, Warwick E. 1990. Experimental exchange of queens between colonies of Melipona compressipes (Apidae, Meliponini). Rev. Bras. Biol. 50(4):975981.

Pirchener, F. 1969. Population genetics in animal breeding. W.H. Freeman and Company. 274p.

Rinderer, T. E. 1986. Selection. In: Rinderer, T.H. (ed). Bee Genetics and Breeding. Academic Press, Inc. New York. p.305 - 322

Rothenbuler, W. C.; Kulincevic, J. M., Thompson, V. C. 1979. Successful selection of honeybees for fast and hoarding of sugar syrup in the laboratory. J. Apic. Res. 18: 272 - 278.

Soller, M.; Bar-Cohen, R. 1967. Some observations on the heritability and genetic correlation between honey production and brood area in the honeybee. J. Apic. Res. 6: 37-43.

Vencovsky, R.; Kerr, Warwick E. 1982. Melhoramento genético em abelhas. II. Teoria e avaliação de alguns métodos de seleção. Brazilian Journal of Genetics, 5(3):493-502.

RECEBIDO EM 05/02/2003

ACEITO EM 03/08/2005 